\title{
GLOBAL ISLAMIC LIBERATION THEOLOGY IN THE LOCAL CONTEXT OF TRANSGENDERED INDONESIAN MUSLIMS
}

\author{
Hary Widyantoro \\ Islamic State Institute of Samarinda, Kalimantan Timur \\ email: haryx10@gmail.com
}

\begin{abstract}
The place of Lesbian, gay, bisexual, and transgender (LGBT) Muslims within Islamic normativity has become attention for scholars and activists, such as Kecia Ali and Scot Kugle, Nur Kholis who rethink the place of LGBT people in social, political, and religious lives. The paper discusses how Islamic liberation theology, as a global concept within the Muslim world, has inspired Nahdlatul Ulama Islamic University scholar-activists to hold discussions about the place of waria in Islam, at the Pesantren Waria Al-Fatah, Yogyakarta. However, as globalization leads to glocalization, the way the concept is understood and implemented differs from that global one. The study argues that global Islamic liberation theology influencing the activists in perceiving waria subject position has undergone "glocalization." As Islamic liberation theology was used to fight against colonialism and capitalism, the scholar-activists now find in it the tools to fight against the oppression towards gender minorities, particularly waria. The study is based on interviews with several Nahdlatul Ulama activists, and participant observation in the Pesantren event.
\end{abstract}

Keywords: transgender, liberation theology, Islam, globalization.

الملخص: أصبحت LGBT من المسلمين في الأعراف الإسلامية موضع اهتمام العلماء

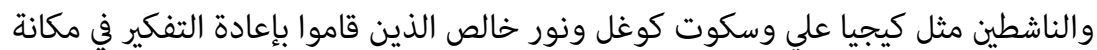

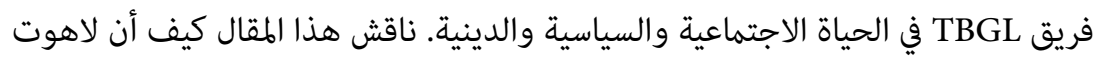

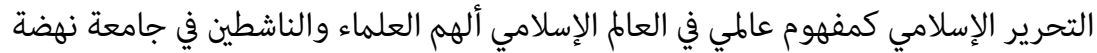


العلماء الإسلامية لعقد نقاش حول مكانة الخنثى في الإسلام في بسانترين ״الفتحه للخنثي

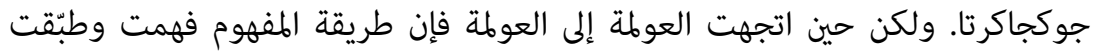

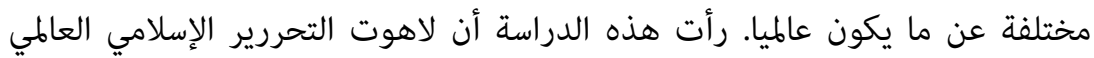

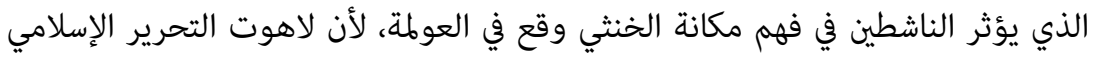

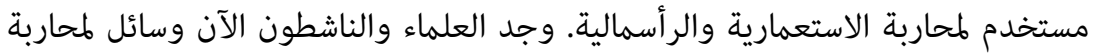

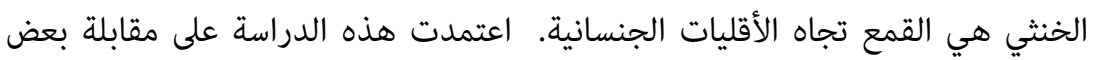
الناشطين من جمعية نهضة العلماء والملاحظة بالمشاركة في أنشطة بسانترين.

Abstrak: Tempat Muslim Lesbian, gay, biseksual, dan transgender (LGBT) dalam normativitas Islam telah menjadi perhatian para cendekiawan dan aktivis, seperti Kecia Ali dan Scot Kugle, Nur Kholis yang memikirkan kembali tempat orang LGBT dalam bidang sosial, politik, dan kehidupan agama. Makalah ini membahas bagaimana teologi pembebasan Islam, sebagai konsep global dalam dunia Muslim, telah mengilhami para cendekiawan-aktivis Universitas Islam Nahdlatul Ulama untuk mengadakan diskusi tentang tempat waria dalam Islam, di Pesantren Waria Al-Fatah, Yogyakarta. Namun, ketika globalisasi mengarah ke glokalisasi, cara konsep dipahami dan diterapkan berbeda dari yang global. Studi ini berpendapat bahwa teologi pembebasan Islam global yang memengaruhi para aktivis dalam memahami posisi subyek waria telah mengalami "globalisasi." Karena teologi pembebasan Islam digunakan untuk memerangi kolonialisme dan kapitalisme, para aktivis sarjana sekarang menemukan di dalamnya alat untuk melawan penindasan terhadap gender minoritas, khususnya waria. Studi ini didasarkan pada wawancara dengan beberapa aktivis Nahdlatul Ulama, dan pengamatan partisipan dalam acara Pesantren.

\section{INTRODUCTION}

On March $28^{\text {th }}$ 2014, Syariah and Law Faculty of NahdlatulUlama Islamic University (UNISNU), Jepara, a university owned by Indonesia's largest Islamic civil society organization, and the Islamic Boarding School (Pesantren) Waria al-Fatah, Yogyakarta, a religious community founded by and for waria, signed an agreement to hold the Religious Practice Partnering Program at the Pesantren, based 
on memorandum of understanding. The Program was to provide the waria $^{1}$ a space to study and to practice Islam, knowing that it is difficult for them to find such place. As a community service program supported by Syariah and Law Faculty, it was planned for a three-year period, from 2014 to 2016 . However, the program was stopped when an Islamic vigilante group, the Islamic Jihad Front, exerted pressure on Yogyakarta authorities and on the surrounding community to close down the Pesantren, as "un-Islamic" and part of a global LGBT movement. The shutdown was part of the anti-LGBT campaign in Yogyakarta and across Indonesia more generally, in the beginning of $2016 .^{2}$ The scholar-activists who had come to teach as an Islam that has room for waria Muslims were clearly different from the Islamic Jihad Front (FJI) or any other groups condemning the existence of the Pesantren. The leader, Nur Kholis, a scholar on Islamic Law, insisted that the program does not aim to gender waria or encourage them to be males as other institutions do, such as Indonesian Ulama Council and previous kyai who had worked with the Pesantren, and FJI. ${ }^{3}$ How are they different? What makes them different, looking at Islamic movements and thoughts map? Another study argued that Islamic Liberation Theology by several Muslims scholars, such as Ashgar Ali Enginer and Ali Syariati has influenced the scholar-activists to rethink the waria subject position in social and religious lives. ${ }^{4}$ Hence, this study explores how Islamic Liberation Theology becomes a concept to liberate waria, and how it

1 Indonesians word for transgender women. The word was first inveted by the Minsitry of Religious Affair following the rejection by Muslims group towards previous word, "Wadam," meaning Hawa Adam Tom Boellstorff, "Playing Back the Nation: Waria, Indonesian Transvestites," Cultural Anthropology 19, no. 2 (May 1, 2004): 159-95, https://doi.org/10.1525/can.2004.19.2.159..

2 "Pesantren Waria Di Yogyakarta Ditutup, LBH Protes," BBC Indonesia, accessed September 27, 2017, http://www.bbc.com/indonesia/berita indonesia/2016/02/160225_indonesia_ponpes_waria_ditutup.

3 Nur Kholis, Program Pendampingan Praktek Keberagamaan Waria, 2015.

4 Hary Widyantoro, "Rethinking the Waria Discourse: The Collaboration between Nahdlatul Ulama Islamic University Activists and Transgender Santri," in Knowledge, Power, and Politics: Where Is Humanity Heading To? (The 7th Internationl Graduate Students and Scholars Conference in Indonesia, Universitas Gadjah Mada: Sekolah Pascasarjana UGM, 2014), http://webcache.googleusercontent. com/search?q=cache:hk1BJINTObEJ:igsci.pasca.ugm.ac.id/v2.0/assets/files/igsc-07054-hary-widyantoro.pdf $+\& \mathrm{~cd}=1 \& \mathrm{hl}=\mathrm{id} \& \mathrm{ct}=\mathrm{clnk} \& \mathrm{gl}=\mathrm{nl}$. 
is contextually reinterprated to be used in the local level that leads to the concept heterogenization, as part of glocalization process.

Six lecturers from Syariah and Law Faculty of Nahdlatul Ulama Islamic University, Jepara volunteered to teach Islam at the pesantren. They are Nur Kholis, S.H.I., M.S.I., in religion and culture, Drs. Ahmad Barowi, M.Ag., in faith and Sufism, Mayadinar. Musfiroh, S.H.I., M.A. in Qur'anic interpretation and hadith, Hudi, S.H.I., M.S.I. in fiqh and worship, and Wahidullah, S.H.I., M.H. in law and human rights. One of them , Abdul Wahab, S.Sos.I., M.S.I., is from the Dakwah Faculty. They had been members of Indonesian Islamic Student Movements (PMII) in their campuses as well as students of Pesantren in their youth. However, Kholis was the one who studied specifically about waria in Islam during his time in Yogyakarta, engaging with them, and then wrote a master thesis about waria religiosities in the perspective of Islamic Law Humanism. ${ }^{5}$ It means a humanistic law that Muslims should have, since Islam consider all different people as humans, created by God, including waria. It considers waria as humans who also have rights to pray and to practice Islam. Thus, he argued that based on Islamic Law humanism, waria are humans created by God, thus we should not condemn them, yet give them space to express religiosities. In this respect, I learned that he defines Islamic law humanism as a law that takes human personal religious experiences into account, as something unique and to be respected. This methodology - phenomenology - sees insider's perspective as an important element in studying religious phenomenon and it has been flourished in $19^{\text {th }}$ century with some works of Rudolf Otto, Smith, and etc. ${ }^{6}$ Regarding the theoretical framework, Khalis referred it to Ali Syaria'ati suggesting that humanist values is to free all people from any oppression, and for the sake of life perfection, human self-consciousness, rejection of tyranny, and protecting worship. Taking this as standing point, Khalis argued there should be fiqh that discusses about waria. ${ }^{7}$ Kholis and his other colleges think

5 Kholis, Program Pendampingan Praktek Keberagamaan Waria.

6 See Wilfred Cantwell Smith, The Meaning and End of Religion (Fortress Press, 1963); Mircea Eliade, The Sacred and the Profane: The Nature of Religion (Houghton Mifflin Harcourt, 1959).

7 Nur Kholis, "Humanisme Hukum Islam Tentang Waria Kajian Filsafat Hukum Islam Tentang Praktik Keagamaan Waria Di Pesantren Khusus Waria Senin-Kamis Yogyakarta" (IAIN Walisongo, 2013), http://eprints.walisongo.ac.id/35/. 
that waria are gender/sexual minorities who should be liberated, inspired by Islamic liberation theology they learned from PMII. For example, Wahab, one of the scholar-activists, contended that religion liberates humankind from being exclusive to being inclusive, being oppressed to being free. Through liberation theology, religion leads to creativity and productivity instead of oppressing other human minority. ${ }^{8}$ Hence, more than gender or feminist theory, it is Islamic liberation theology has inspired and helped the scholar-activists in seeing waria religiosities at the Pesantren Waria al-Fatah Yogyakarta and has become a concept to liberate waria. $^{9}$

This study seeks to understand the production of knowledge taking place, based on an encounter between the scholar activists from Syariah and Law Faculty of Nahdlatul Ulama University of Jepara and waria santri, through the process of rethinking and reconstructing the waria subject position in Islam. It deals with how the production of knowledge takes place, specifically in response to the fact that waria are marginalized. Additionally it also seeks to understand what motivates them to engage in this activity, Namely, what are the ideas that frame their support and justify their activism?

Furthermore, this study is a critical instrument in the field of both gender and Religious Studies, to comprehend how these scholaractivist create new ways of seeing waria from Qur'an and hadith and of teaching Islam to them. It is so because no study has focused on non-waria, Muslims scholar-activist, since other studies mostly discussed and see waria as object of research. This study, moreover, shows how the process of rethinking offers hopes for those who do not fit in male and female gender binary.

\section{GLOCALIZATION AND ETHNOGRAPHY, AS THEORETICAL FRAMEWORK AND METHODOLOGY}

The study considers glocalization as a concept and theoretical framework to critically describe, and make sense the process of waria religiosities discourse-making by seeing the encounter between waria santri and Nahdlatul Ulama activists from Jepara in the Pesantren

\footnotetext{
8 Abdul Wahab, Islamic Liberation Theology, 2015.

9 Widyantoro, "Rethinking the Waria Discourse: The Collaboration between Nahdlatul Ulama Islamic University Activists and Transgender Santri."
} 
Waria al-Fatah Yogyakarta. To study this encounter, furthermore, ethnography has taken its place as a methodology to collect the data.

This already globalized world has been creating hybrid identities, understandings, and actions, so that scholars must pay attention how the actor connect themselves to the global world and discourse, yet undergo the process of re-contextualization in the local context. This has been the strategy for every individual and movement in many places, that is well-known as glocalization as popularized by Robertson. This concept term is originated from the Japanese practice of dochakuka, meaning global localization; adapting a global institution practices to local condition. Many companies produced innovations that have been successful in the local level are fed back into global system, which contributed in keeping them globally competitive, caused by their flexibilities. ${ }^{10}$ Hence, this glocalization process shows us how globalization produces such hybridity where global and local institutions are negotiating. For example, Christian Churches have been flexible in responding what they call heresy and syncretism, as local worldview and needs on the one hand, and have to always craft symbolic goods to maintain the orthodoxy and hierarchy at their global movement, on others. ${ }^{11}$

This study is based on five months of fieldwork in 2015, including interviews and participant observation at the Pesantren Waria alFatah Yogyakarta and the UNISNU Campus Jepara, including the process of its closing down by FJ, during anti LGBT campaign in the beginning of 2016. Beside interviewing six scholar-activists to understand how they constructed the waria discourse in Islam, I also draw the Pesantren history based on the interview with ShintaRatri who assumed the leadership in 2004, following the death of the former leader, Maryani. Furthermore, interviewing PMII members about its training members, knowing that all the scholar-activists were active in the organization, is taken into consideration which then led me to see the Islamic Liberation Theology influences.

${ }^{10}$ Roland Robertson and others, "Glocalization: Time-Space and HomogeneityHeterogeneity," Global Modernities 2 (1995): 28.

${ }^{11}$ Manuel A Vasquez and Marie F Marquardt, Globalizing the Sacred: Religion Across the Americas (Piscataway: Rutgers University Press, 2004), 56-57, http://site. ebrary.com/id/10075356. 


\section{ISLAMIC LIBERATION THEOLOGY AND WARIA SUBJECTIVITY}

This part explores some studies of Islamic liberation theology as a concept developed and took place in Muslims societies or communities in both Muslims and non-Muslims majority countries. It discusses the concept's history through questions like where was the concept developed? What was the context? What contributes to its emergence? Those kind of questions help us understand and link to Khalis's interpretation of Islamic liberation theology and its implementation in a local context.

Alexandra Van Den Heever, in her study on Islamic Liberation Theology, compared Islamic liberation theology and post-Islamism development, considering that both have similar ideas on equality struggle. She found that Islamic liberation theology developed in non-Muslim majority countries, while the last did in Muslim majority countries. For example, Esack and Enginer idea of liberation theology did not developed in Middle East since it is where Muslims are majorities, yet it developed in non-Muslims majority countries because they face the oppression due to their minority status and religious difference. Unlike the liberation theology, the postIslamism, as Asef Bayat called, developed in majority Muslims countries. Each developed in different context, place, and struggle. On the one hand, post-Islamists may be able to push for equality through government participation and the passing laws, while those engaging with Islamic liberation theology have to struggle more than the Islamist does to enjoy the same privileges as post-Islamists do, due to their minority status that forces them to struggle. While postIslamism, as developed in majority Muslims countries, is allowed to be flourished since the governments are mostly Muslims. ${ }^{12}$ Looking at the scholar-activists and waria case, they live in Muslims majority country yet each has different case. Islamic liberation theology has been becoming one of material discussions in PMII training members, and has inspired many of its members to liberate either themselves or other facing oppression, such as what the scholar activists did. In this

${ }^{12}$ Alexandra van den Heever, "Islamic Liberation Theology" (Wheaton College (Norton, Mass.), 2014), https://digitalrepository.wheatoncollege.edu/bitstream/ handle/11040/23887/FINAL\%20THESIS\%20-\%20VAN\%20DEN\%20HEEVER. pdf;sequence $=1$. 
respect, the scholar-activists used, developed, and contextualized Islamic liberation theology in Muslims majority country to liberate waria as gender/sexual minority.

Furthermore, Kurzman included Islamic liberation theology idea as part of liberal Islam that brings the idea of liberation, equality, and humanism rooted from the Catholic Liberation theology in Latin America. He mentioned several Muslims thinker propagating Islamic liberation theology, such as Engineer, Esack, Abdurrahman Wahid, and Abdullahi an-Na'im. The rise of liberal Islam thought follows the establishment of secular higher education in the Islamic world, the growth of international communication, which contributes to educated Muslims' awareness on the western norms and institutions, and the failure of Islamic regime to implement a good governance are those leading liberal Islam thought to grow in Muslims world. ${ }^{13}$

As Van den Heever and Kurzman draw, Islamic liberation theology proposes the idea of liberation from oppression, equality, and humanism, as engineer, Ali Syari'ati, Esack, Na'im, Abdurrahman Wahid, and other have brought. Those thinkers are included as liberal Islam movements by Kurzman. However, how the term "liberal" is generally understood in Indonesia might be different from how Kurzman and other scholars see. Many Indonesians, including politician explicitly reject the idea of liberalism, followed by Indonesian Ulama Council (MUI) fatwa. It can even be a weapon to attack other politicians, scholars, or activists since the word is generally interpreted as an idea of free thought without limit that endanger religious teachings. Thus, the conservatives sometimes use it to attack LGBT advocacy activists that the movements and its supporters are liberals endangering religious teachings. However how the scholar-activists of UNISNU understand Islamic liberation Theology fits to Kurzman and Van den Heever illustration that it consists of the idea of liberation from oppression, and the struggle for equality and humanism. This can be seen how they perceive waria as gender/sexual minority that should be liberated and be respected equally, rather than as people who are sexually deviant and sick.

Looking more closely at the study on transgender and LGBT, more broadly, I found that Boellstorff and Kholis considered waria

${ }^{13}$ Charles Kurzman, "Liberal Islam: Prospects and Challenges," Middle East 3, no. 3 (1999): 12. 
subjectivities, as the term that Foucault developed, that gays, lesbians, and waria are becoming subjects of their beings. Foucault described that subjectivity is how individuals are led to recognize themselves as subject of desire, sexualities, and more importantly of the truth of their beings by certain form of discourse. ${ }^{14}$ In this case, Kholis and other activists consider waria subjectivities by allowing them to practice religion based on how they feel comfort, either in men or women ways. ${ }^{15}$ Maryani, the former Pesantren leader, once said that she was neither male nor female, yet waria and it is destiny given by God. She did not want to do genital surgery, yet thanked God for what she had. She would keep worshipping God, even though some ulama rejected because God decides, at the end. The idea is based on his master thesis on Islamic Law Humanism discussing waria matter in Islam. He found that there is legal vacuum in fiqh regarding waria matter so that Islamic Law Humanism insisted there should be fiqh discussing transgender matter. ${ }^{16}$

Boellstorff's idea of "Dubbing Culture," led me to recognize the local term of "Waria" rather than using transgender, as global one, to deeply illustrate the agency of the actors. Boellstorff illustrated how Indonesian Gay and Lesbi understand their subject position through encountering with the global media, yet preserve a gap in meaning to the local. He used the voiceover dubbing into Indonesian of imported TV programs, as an analogy. ${ }^{17}$

Besides, Kecia Ali and Scott Kugle also engage is the discussion of LGBT questions on religious and social lives. For example, Kecia Ali discussed about same sex intimacy in Muslims thought, contending that same sex intimacy cannot be excluded from any discussion about sexual ethic. Finally she compared the long term consensual samesex relationship with the series marriage and remarriage, and slave concubine, then posted the question whether the second is morally

${ }^{14}$ Michel Foucault and Robert Hurley, The Use of Pleasure (London: Penguin Books, 1992), 5, 30.

${ }^{15}$ Men and women have different ways of pray in Islamic tradition, in terms of dressing (modesty), recitation (based on Arabic grammar), and who can lead prayer.

${ }^{16}$ Kholis, "Humanisme Hukum Islam Tentang Waria Kajian Filsafat Hukum Islam Tentang Praktik Keagamaan Waria Di Pesantren Khusus Waria Senin-Kamis Yogyakarta."

${ }^{17}$ Tom Boellstorff, "Dubbing Culture: Indonesian Gay and Lesbi Subjectivities and Ethnography in an Already Globalized World," American Ethnologist 30, no. 2 (May 1, 2003): 225-42, https://doi.org/10.1525/ae.2003.30.2.225. 
better than the first is? Considered unlawful, is the first worse than the second?. ${ }^{18}$ Moreover, Kugle suggested that Qur'an al-Syuraa (26: 160-173) discussing Lot story can be read as a critique towards male sexuality driven by aggression, subjugating other by force, and rape, rather than as homosexuality condemnation. It even does not explicitly discuss homosexuality. Like Kholis who argued about referring transgender to mukhanath term rather than khuntha, Kugle also discussed transgender referring to mukhanath in his book and describe it as gender problem rather than sexual orientation. ${ }^{19}$ This is also what I have to emphasize that even though transgender is part of global LGBT discourse, it has differences from other such as Lesbian, Gay, and Bisexual. Those three are more about sexual orientation, while transgender is about gender roles and expressions.

The more recent work by Benjamin Hegarty, who studied transgender women in Indonesia, tells us how transgender connect themselves to the global scope of transgender that is related to global political economy. Many of them charge money for interview and other media appearances, since transgender globalization and its relationship to human right are connected to media interest, especially transgender religious lives, where many transgender and LGBT people in Western countries live out the churches. It is unavoidable that Western media give much attention to the relation between transgendered people and Islam, where they hardly find the case in the west. ${ }^{20}$ This work encourages me to pay attention to how transgender and the discourse in the local context is connected to the global world.

\section{GLOCALIZING ISLAMIC LIBERATION THEOLOGY TO LIBERATE WARIA}

As a concept challenging the oppression either by colonialism or capitalism, it inspires many Muslims around the world to struggle against them for better lives, including the waria religiosities case

\footnotetext{
${ }^{18}$ Kecia Ali, Sexual Ethics and Islam: Feminist Reflections on Qur'an, Hadith and Jurisprudence (Oneworld Publications, 2015), 96.

${ }^{19}$ Scott Siraj al-Haqq Kugle, Homosexuality in Islam: Critical Reflection on Gay, Lesbian, and Transgender Muslims (Oneworld Publications, 2010).

${ }^{20}$ Benjamin Hegarty, "The Value of Transgender Waria Affective Labor for Transnational Media Markets in Indonesia," TSQ: Transgender Studies Quarterly 4, no. 1 (February 1, 2017): 78-95, https://doi.org/10.1215/23289252-3711553.
} 
as contended by the scholar-activists. However, how the actors comprehend the concept may differ one another, depending the context that they have and the problem they face. While keeping connecting the concept to the global one, leading them to be always being linked to the whole world, they also undergo the process of contextually re-understanding, rethinking, and re-interpreting, to make the concept applicable. If we study how Enginer discussed Islamic Liberation Theology, or Ali Syariati and Hasan Hanafi as PMII members included, they basically call all Muslims to fight against the oppression caused by colonialism, capitalism, and even westernization. However, UNISNU scholar-activists, especially Nur Kholis, differently used the concept in the sense that they fight against the oppression caused by the dominant discourse on gender binary, rather than capitalism or colonialism. Male and female gender binary has put the waria out of nowhere that consequently raised difficulties for them in social and religious lives. This process of glocalization is embodied in scholar-activists view on waria; first, they see them as the oppressed minority and second, they insisted that there should be human (gender) equality and no male-female gender binary dichotomy before the law. Hence, Islamic liberation theology gained its new formation in the local context, which is the liberation of waria from male-female gender binary concept.

In PMII training members, not only do they include several thinkers such as Ali Syari'ati, Hasan Hanafi, and Abdurrahman Wahid as Islamic Liberation theologies theorists, but also historically discusses the Latin American one, as that influencing other. ${ }^{21}$ Islamic liberation theology has brought the activists to the understanding of transgender as gender difference and gender minority rather than gender deviance, while many Indonesians even scholars categorize them as gender/sexual deviant. For example, during anti LGBT campaign in Indonesia at the beginning of 2016, psychiatrists and government insisted LGBT people are deviant. Natsir, the former

${ }^{21}$ Widyantoro, "Rethinking the Waria Discourse: The Collaboration between Nahdlatul Ulama Islamic University Activists and Transgender Santri," 60; Nur Santoso, Sekolah Pemikiran Aswaja Dan Teologi Islam PR Eksakta. (PMII Komisariat STAI Ibrahimy, Banyuwangi, 2014). 
of ministry of education and culture argued LGBT people should be banned from entering campuses. ${ }^{22}$

The next sub chapters explore the process in which the formationmaking of Islamic liberation theology took place, which begins from waria as an oppressed minority, equality as humans, and negotiation between global and local.

\section{Waria as an oppressed minority}

Seeing waria as the oppressed minority gives significant difference towards how they treat and behave towards them, rather than those who see the waria as deviants who should be masculinized, normalized and healed. This view then provide a room for waria in social and religious lives, while the second has contributed in excluding waria from normal life as citizen, humans, and people who want to express religiosities. This indeed is different from how Enginer and Syari'ati theorized about fighting against the oppression, in which capitalism and colonialization are the causes. To the activists, gender binary is that bringing waria to an exclusion and oppression. This shows that the scholar-activists underwent the glocalization, in which they connected themselves towards global Islamic liberation theology, while contextualized it as a strategy at the local level. Even so doing, the scholar-activists tough did not provide a clear alternative, whether waria should be in a third gender other than male and female binary, such as hijra in Bangladesh, Pakistan, and India.

The activists willingness to help minority, waria at the Pesantren to learn and to practice religion is derived from humanism consideration, as the idea of Islamic law humanism. This willingness has been grown through intellectualism, as lecturers, activists both inside and outside campus. For example, Mayadina, one of the activists who considered waria as minority, explained:

There is one minority community (waria), yet their existence is unknown. Even though unknown, society knowledge about this

${ }^{22}$ C. N. N. Indonesia, "Menristek Sebut LGBT Tak Dibolehkan Masuk Kampus," CNN Indonesia, accessed September 30, 2017, https://www.cnnindonesia. com/nasional/20160123211552-20-106213/menristek-sebut-lgbt-tak-dibolehkanmasuk-kampus; "MUI: Waria Tak Boleh Jadi Imam Jamaah Wanita," Republika Online, accessed September 30, 2017, http://republika.co.id/berita/dunia-islam/islamnusantara/15/03/08/nks07q-mui-waria-tak-boleh-jadi-imam-jamaah-wanita; "Fatwa MUI: KEDUDUKAN WARIA” (Majlis Ulama Indonesia, October 11, 1997). 
community is shallow. In social terms, they can be called an excluded community. Besides, as a minority, only few do care about them, especially regarding religious matter, yet, in fact, they are real. Since they are minority, it is interesting to help and to learn about them as well. ${ }^{23}$

Abdul Wahab, another activist who has been a friend of Kholis's since they were involved in PMII organization, also described the willingness to help this minority. As he explained this kind of willingness is grown and is common in PMII nature, during their time. "If we found certain community discriminated, we were ready to partner them. This kind of nature was common," he added. ${ }^{24}$ This is based on the idea of Islamic liberation theology they have learned in PMII, that religion should not be occupied by certain people defining right and wrong, rather intellectuals should critically involve in defining it. Thus, Islam must liberate people rather than oppressing them.

\section{Equality as Humans}

This is how the Islamic liberation theology underwent the process of glocalization, in which the oppression they perceived was caused by male and female gender binary, rather than capitalism or colonialism. This led them to consider waria as humans and then to the idea about gender equality, that state and religious institutions should equally recognize them, in terms of constitutional, civil, and human right to live and to express religiosities. For example, waria should be able to have access to education, health, and political participation as equal as other are, as constitutional right. The right to express religiosities means that they should be able to express religiosities in their own ways.

Wahidullah, a UNISNU lecturer in Jepara, stated that Indonesian constitution is clear about human right, in terms of waria constitutional right to live. If we perceive that all humans are equal including waria, then there should be no male and female gender dichotomy that consequently contributed in discriminating them. ${ }^{25}$

${ }^{23}$ Mayadina Rohma Musfirah, Program Pendampingan Praktek Keberagaman Waria, 2015.

${ }^{24}$ Wahab, Islamic Liberation Theology.

${ }^{25}$ Wahidullah, Islamic Liberation Theology, 2015. 
Furthermore, Wahab, who is also an Islamic preacher, contended that the only distinguishing humans before God is their devotion, not based on gender difference. If the waria have devotion quality, why should we claim their worship is unaccepted? If preachers claim that way, religion will have the cruel image and will not be a solution to abolish the oppression. Considering all humans as equal including waria will inspire the waria to learn religion, which is better than judging them as deviant, he added. ${ }^{26}$ Contending that waria are an invisible and excluded community, another of the lecturers, Mayadina, argues they should be recognized both in social and religious context. This program, she said, invited religious leaders and authorities to realize that waria are exist, not deviant, and should not be marginalized, thus social recognition comes after religious discourse recognition. ${ }^{27}$

Another important topic to discuss is how waria sexualities and marriages are, as important aspects of human lives. What should be recognized? What are the limits of humanism? Even though all the activists insisted that waria should be recognized, only did Kholis deeply discuss it, as his intellectual interest. The five other only discussed the importance of respecting the waria if they get married, and sin is God's matter. The heterosexual majorities cannot judge waria as minority based on their majority perspective. Other than that, Kholis discussed waria sexualities, marriages, and religious lives, including whether or not they can do genital surgery. These all are part of fiqh waria discussion that he has been thinking, like working paper. So fiqh waria is a manifestation of Islamic legal humanism. In Indonesia, many people who reject waria base their argument on that waria are part of LGBT discourse and political movement that is western construction. This leads to bias that connecting waria to LGBT discourse without defining each category cause them to be linked to sexual desire. So talking about waria is mostly about sexual desire and there is no space to discuss the fiqh. Hence, this is that which leads to many people's rejection.

Iran has an interesting case, regarding Islamic Government policy on trans people, where genital surgery is permissible and they may get married. All though global discourse on third gender are not really discussed, trans people may undergo medical check by the doctor

\footnotetext{
${ }^{26}$ Wahab, Islamic Liberation Theology.

${ }^{27}$ Musfirah, Program Pendampingan Praktek Keberagaman Waria.
} 
and obtain trans certificate, then are allowed to do genital surgery. This policy is based on fatwa issued by Khumeini as the one who is considered as an expert in figh and has political authority, even though several doctors and Muslims jurist oppose the fatwa. The debate was basically on the discourse of sexual change surgery that was colored by medical, physiological, and fiqh discourse, which then was followed by fatwa by Khumeini. ${ }^{28}$ Furthermore, in Bangladesh, hijra as distinct gender category just linked to sexual desire, following the "men having sex with men"-based NGO intervention that eventually created new discourse on hijra and sexuality. On the contrary, most non-hijra people perceived them as those living without desire. This means even though legal recognition of hijra as distinct gender emerged, it does not link them to sexual desire and marriage. Lot of NGO consider hijra as those who need specific sexual health needs, as well as what happen in India. ${ }^{29}$

Moreover, Kholis's first impression, regarding fiqh waria, was that many referred the transgender phenomenon to the term khuntha (hermaphrodite), rather than mukhanath ${ }^{30}$ on the one hand, and many discussions is only about whether or not they are accepted, on the other. No discussion on marriages, sexualities, praying, and other social religious matters. I assumed he has not yet read Najmabadi's book on transgender in Iran, The Professing Selves. This work explores how the Islamic Republic of Iran allowed transgendered women to have genital surgery, after passing certain test. This shows the relation between Islamic government, mufti, fuqaha and Transgenderism, in the sense that the government acknowledged transgender as one humans category. It is a room for transgender, even though the government may consider transgenderism as deviance, which like

${ }^{28}$ Afsaneh Najmabadi, Professing Selves: Transsexuality and Same-Sex Desire in Contemporary Iran, (Durham:Duke University Press, 2014), 173-78.

${ }^{29}$ Adnan Hossain, "The Paradox of Recognition: Hijra, Third Gender and Sexual Rights in Bangladesh," Culture, Health \& Sexuality 19, no. 12 (December 2, 2017): 1418-31, https://doi.org/10.1080/13691058.2017.1317831.

30 It is a term for men who act like women that is described in hadith and interpreted by al-Nawawi. Besides, al-Asqalani also used the term, and both fuqaha categorize mukahants into min khalqin (by nature) and bi takallufin (by nurture) see Kholis, "Humanisme Hukum Islam Tentang Waria Kajian Filsafat Hukum Islam Tentang Praktik Keagamaan Waria Di Pesantren Khusus Waria Senin-Kamis Yogyakarta." 
homosexuality, should be "solved". ${ }^{31}$ Back to Kholis argument on fiqh waria, itis very significant in recognizing waria religiosities based on gender consciousness. He further discussed waria marriage by taking the case of the celebrity transsexual Dorce Gamalama as an example. Considering her as mukhanath khalqi, Dorce can marry a man and genital surgery becomes wife-husband relation consideration. The surgery might be primary needs if it contributes to the more intimate sexual relationship. However, if it emerges as an option that the couple are satisfied with the condition, than it only becomes mandub (recommendation). ${ }^{32}$

Other than that, Mayadina stated that we cannot avoid the fact that the marriages or sexual relationship between waria and men have happened. Psychologically, they are females but have male bodies and many cannot lie to themselves about the attractiveness towards males. So letting the relationship happens and letting them to be in charge of their act would be a wise act. However, considering Indonesians are not ready yet for such thing, she emphasized not doing it publically. ${ }^{33}$

\section{Negotiation between Global and Local}

As Vazquez and Marquardt explained how glocalization shows us that globalization does not necessarily homogenize the cultures, rather it creates tension between heterogeneity and homogeneity, in which both the global and local actors must negotiate. ${ }^{34}$ This kind of negotiation became a process that the scholar-activists underwent, especially Kholis who has been engaging with the waria at the Pesantren and then developed the idea of Islamic law humanism, based on the Islamic liberation theology concept. While the concept as they learned was to fight against the oppression that was not caused by gender binary idea. As he involved and was conducting

${ }^{31}$ Najmabadi, Professing Selves.

${ }^{32}$ Kholis, Program Pendampingan Praktek Keberagamaan Waria. See more the figh waria discourse in Hary Widyantoro and Ph D. Gregory Vanderbilt, "Rethinking Waria Discourse in Indonesian and Global Islam: The Collaboration between Nahdlatul Ulama Islamic University Activists and Waria Santri" (Universitas Gadjah Mada, 2015), 80-83, http://etd.repository.ugm.ac.id/index.php?mod=penelitian detail\&sub=PenelitianDetail\&act=view\&typ=html\&buku_id=88126\&obyek_id=4.

${ }_{33}$ Musfirah, Program Pendampingan Praktek Keberagaman Waria.

${ }^{34}$ Vasquez and Marquardt, Globalizing the Sacred, 57. 
participant observation at the Pesantren, he then came up to the understanding that they are the oppressed minority caused by gender binary idea. This indeed shows us that the re-contextualization and reinterpretation of global Islamic theology at the local level has happened. This illustration indicates that the global Islamic liberation theology does not necessarily lead to homogeneity, rather heterogeneity as a result of global and local negotiation process.

The process is first, the NU activists learned about Islamic liberation theology in PMII training members. The central idea of the concept is equality, liberation from oppression, democracy, and soon. They actively had discussions on politic, culture, religion, using the concept as one of analytical tools. Kholis for example was well-known among his colleges as a gender (male and female) expert. However, as he got more interested on gender, he found what he was thinking as non-male and female gender binary, which is waria, after reading ShuniyaRuhama's book, Jangan Lepas Jilbabku (Don't Remove my Veil!). She was Gadjah Mada University transgendered student who wore the Islamic veil in early 2000s, at the time it marked Muslim student identity in relation to the state, and insisted on wearing it as her right as a pious and feminine Muslim, based on her gender consciousness. During this, veil is quite important for women who were reconciling the opport unities for autonomy and choice provided by modern schools, followed by the growing awareness of being Islamic, as commitment to Islam..$^{35}$ Soon Kholis met this waria and then moved to Yogyakarta in 2009 to study about waria at the Pesantren. ${ }^{36}$

Kholis found that waria did not fit in male-female gender binary. This narration also appeared when I interviewed the other scholaractivists. This is then what they think the source of the problem, and what I call as rethinking gender binary process. Hence, the waria are considered as the oppressed minority that should be liberated. In short, after engaging with the waria at the Pesantren, Kholis developed and then wrote the thesis on Islamic law humanism, as a humanistic law that liberates waria from oppression caused by male-female gender

${ }^{35}$ Nancy J. Smith-Hefner, "Javanese Women and the Veil in Post-Soeharto Indonesia," The Journal of Asian Studies 66, no. 2 (May 2007): 389-420, https://doi. org/10.1017/S0021911807000575.

${ }^{36}$ Kholis, Program Pendampingan Praktek Keberagamaan Waria. 
binary. He based this idea on Islamic liberation theology. After he graduated from State Islamic University of Walisongo, Semarang, he began teaching at UNISNU Jepara then held the Religious Practice Partnering Program, a collaboration between Syariah and Law Faculty and Pondok Pesantren al-Fatah, Yogyakarta, as a community service by the faculty.

\section{GENDER BINARY DISCOURSE IN BOTH THE EAST AND WEST}

This chapter shows how different local actors react to the concept of male-female gender binary concept and its counter, third gender concept. It is important to see different cases such as Bangladesh, Pakistan, United States and United Kingdom, where each has different history and culture regarding trans people recognition both in cultural-social lives and legal aspect, in order to study how different local actors engage in the discourse.

Regarding the male-female gender binary excluding waria as Kholis argued, it is interesting to see the development and discussion on the non-binary gendered people discourse, as some call third gender, and their struggle to obtain recognition, in which transgender is part of them. For example, the Superior Court of California has approved the bill 179 on gender recognition act. The law uses the term "nonbinary" to describe those with gender identity that do not fit as male or female and who identify not as they were assigned at birth. The bill was a response to verbal harassment and discrimination faced by the non-binary people, and then insists that it is their civil right to be recognized and accurately identified, including on their identity card. The law specifically explains that they can have their birth certificate and drive license changed. ${ }^{37}$ In United Kingdom, several institutions such as Royal Mail, High Street Banks, Government Departments and some universities started using $\mathrm{Mx}$ as a gender neutral tittle on official documents, including driving licenses. This tittle is usually used by transgendered people or individual who identify themselves as neither male nor female. Besides, Oxford English Dictionary would also add the tittle in the database. Johnathan Dent, assistant editor of

${ }^{37}$ Roxas, "Recognition of a Third Gender: A Reason to Celebrate," San Francisco Chronicle, July 13, 2017, http://www.sfchronicle.com/opinion/openforum/article/ Recognition-of-a-third-gender-a-reason-to-11287662.php. 
the dictionary, argued that this shows how English language is able to adapt to an ever-changing society, instead of dictating people's identity. ${ }^{38}$

In Pakistan, well known with its hijra (trans) community, the Chief Justice ordered the authorities to guarantee that hijra, consisting of transvestites, eunuchs (those assigned as males but underwent castration), transgender men and women, and hermaphrodites have their civil right and not to be harassed. These people are perceived as transgender by the bill proposed by hijra activists, in which the Act may be called the Transgender Persons (Protection of Rights) Act, 2017. The hijra of Pakistan often live in slum areas, begging and dancing at carnivals and weddings for living, while some become prostitutes. They are generally shunned by Pakistan conservative society. Hence, as the Chief Justice, Chaudhry ordered the government to give national identity cards showing their distinct gender, as a step to avoid the harassment. In the following years they achieved several legal victories, such as a right to vote, to inherit property, and equal opportunity in education and employment. In 2016, a group of Pakistani clerics issued a religious edict discussing hijra marriage. It said that transgender people with "visible signs" of male or female could marry the opposite sex. ${ }^{39}$

Bangladesh, also well-know with its hijra (trans) community, may have different problem, as Hossain narrated that the hijra legal recognition fallen into paradox with the cultural one. He contended that hijra have long been culturally recognized, yet the legal one is excluding some of them. In other words, some who were part of hijra community are excluded under the new recognition that Hijra are perceived as third gender by the government. Hijra basically means, as they defined, male bodied-feminine identified, or feminine

${ }^{38}$ By Callum Paton For Mailonline, "A New Title for Transgender People Will Join Mr, Mrs and Miss,” Mail Online, May 3, 2015, http://www.dailymail.co.uk/news/ article-3066043/A-new-title-transgender-people-join-Mr-Mrs-Miss-used-drivinglicences-bank-details-government-departments.html.

39 "Pakistan: A Legal Victory for Eunuchs - The New York Times," accessed November 27, 2017, http://www.nytimes.com/2009/12/24/world/asia/24webbriefsALEGALVICTOR_BRF.html; "Transgender Pakistanis Win Legal Victories, but Violence Goes On - The New York Times," accessed December 4, 2017, https://www. nytimes.com/2017/08/19/world/asia/pakistan-transgender-bill.html. 
gendered person and has ability on hijragiri, ${ }^{40}$ and mastering ulti (secret language). Through these ability, one can be considered as hijra. Following Government legal recognition on hijra as the third gender, the ministry of social welfare interviewed some hijra to be clerks or assistant working at their office, in 2015. Hence, they held medical exam to determine whether the interviewed hijra are real. However, as their perception on hijra, as those many non-hijra perceive, is a person who was born as male and did genital surgery or castrated, asexual, or born with missing or ambiguous genital, the problem appeared, since they found some have penis. Thus, they considered those hijra as fake and gang of male bodied who impersonated hijra to obtain job. Hossein then contended this legal recognition has created new discourse on hijra as third gender, who are disabled with genital difference delinked from sexual desire, which then excluded them. ${ }^{41}$

It is interesting to see the contestation and dynamic of third gender or non-binary discourse. Pakistan may have different definition of transgender from those the west has. According to National Center for Transgender Equality, as that which develops in the west, transgender is an adjective and a term for those whose gender identity, expression and behavior is different from that which was assigned at birth. On the other hand, Pakistan, Bangladesh, and India may have different problem with the term. Pakistan defined transgender as hijra, consisting of transvestites, eunuchs (those assigned as males but underwent castration), transgender men and women, and hermaphrodites, as the Transgender Persons (Protection of Rights) Act, 2017 explained. Other than that, Bangladesh has a problem with hijra recognition in legal context.

It shows the third gender discourse development in western countries, specifically in the United States and United Kingdom, where social recognition is followed by the legal one, such as gender identity recognition in the official documents, either as trans or other non-binary. In Asia, the term third gender and transgender and its legal recognition might consist of different concept, case, and implication. The celebration of legal recognition that takes at the west might not

${ }^{40}$ A ritual of badhai (conferral of blessing on the newborn children after they held them in arms as they dance), cholla (tolls collection from within jurisdiction)

${ }^{41}$ Hossain, "The Paradox of Recognition." 
cover the celebration in Bangladesh, India, and Pakistan, even though its legal recognition often adopt the global term of transgender and third gender. As Hossain contended the legal recognition in Bangladesh led to some hijra whoe were culturally recognized to be excluded from third gender or non-binary community. The important question that we have to answer is that whether or not the legal recognition of transgendered people in Asia is as significant as those in the west.

This is the negotiation of a set of actors at the local level that shows us how globalization creates heterogeneity against impulses towards homogeneity. In the concepts of Islamic liberation theology, its interpretation and implementation, there is room for creative, liberating responses to local questions and people.

\section{CONCLUSION}

Thispapershows how the global Islamicliberation theology understood by the scholar-activists of NahdlatulUlama Islamic University has undergone the process of glocalization as part of the globalization phenomenon. The scholar-activists' views on waria show the process of glocalization, such as seeing waria as the oppressed minority and insisting that there should be gender equality, especially for those who do not fit male and gender binary, including the waria. Another example is that the activists did not use the global discourse of LGBT, human right, and marriage equality, that were used by those opposing the waria, rather used Islamic liberation theology to see waria as the oppressed. Accompanying the glocalization process, negotiation between global and local also becomes an important aspect of the process. The negotiation keeps happening as that linking between the global and the local, and heterogenization culture.

Hence, the Glocalization put the activists in the map of global Muslims world using the concept of Islamic liberation theology and automatically link them to the global world. While connecting themselves to the global world by using the global concept, they underwent the process of negotiation at the local level to make the concept applicable. Thus they are always ready for the new invention, ideas, and strategies. This is what makes many transnational movements survived. Flexibility to be in between global and local is in high necessary because many what happens at the local level are 
different from those at the global. This condition leads individuals to be more flexible.

\section{BIBLIOGRAPHY}

Ali, Kecia. Sexual Ethics and Islam: Feminist Reflections on Qur'an, Hadith and Jurisprudence. Oneworld Publications, 2015.

Boellstorff, Tom. "Dubbing Culture: Indonesian Gay and Lesbi Subjectivities and Ethnography in an Already Globalized World." American Ethnologist 30, no. 2 (May 1, 2003): 225-42. https://doi.org/10.1525/ae.2003.30.2.225.

. "Playing Back the Nation: Waria, Indonesian Transvestites." Cultural Anthropology 19, no. 2 (May 1, 2004): 159-95. https:// doi.org/10.1525/can.2004.19.2.159.

Eliade, Mircea. The Sacred and the Profane: The Nature of Religion. Houghton Mifflin Harcourt, 1959.

"Fatwa MUI: KEDUDUKAN WARIA." Majlis Ulama Indonesia, October 11, 1997.

Foucault, Michel, and Robert Hurley. The Use of Pleasure. London: Penguin Books, 1992.

Heever, Alexandra van den. "Islamic Liberation Theology." Wheaton College (Norton, Mass.), 2014. https://digitalrepository. wheat oncollege.edu/bitstream/handle/11040/23887/ FINAL\%20THESIS\%20-\%20VAN\%20DEN\%20HEEVER. pdf;sequence $=1$.

Hegarty, Benjamin. "The Value of Transgender Waria Affective Labor for Transnational Media Markets in Indonesia." TSQ: Transgender Studies Quarterly 4, no. 1 (February 1, 2017): 7895. https://doi.org/10.1215/23289252-3711553.

Hossain, Adnan. "The Paradox of Recognition: Hijra, Third Gender and Sexual Rights in Bangladesh." Culture, Health \& Sexuality 19, no. 12 (December 2, 2017): 1418-31. https://doi.org/10.108 $0 / 13691058.2017 .1317831$. 
Indonesia, C. N. N. "Menristek Sebut LGBT Tak Dibolehkan Masuk Kampus." CNN Indonesia. Accessed September 30, 2017. https://www.cnnindonesia.com/nasion al/20160123211552-20-106213/menristek-sebut-lgbt-takdibolehkan-masuk-kampus.

Kholis, Nur. "Humanisme Hukum Islam Tentang Waria Kajian Filsafat Hukum Islam Tentang Praktik Keagamaan Waria Di Pesantren Khusus Waria Senin-Kamis Yogyakarta." IAIN Walisongo, 2013. http://eprints.walisongo.ac.id/35/. 2015.

Kugle, Scott Siraj al-Haqq. Homosexuality in Islam: Critical Reflection on Gay, Lesbian, and Transgender Muslims. Oneworld Publications, 2010.

Kurzman, Charles. "Liberal Islam: Prospects and Challenges." Middle East 3, no. 3 (1999): 12.

Mailonline, By Callum Paton For. "A New Title for Transgender People Will Join Mr, Mrs and Miss.” Mail Online, May 3, 2015. http://www.dailymail.co.uk/news/article-3066043/Anew-title-transgender-people-join-Mr-Mrs-Miss-used-drivinglicences-bank-details-government-departments.html.

"MUI: Waria Tak Boleh Jadi Imam Jamaah Wanita." Republika Online. Accessed September 30, 2017. http://republika.co.id/ berita/dunia-islam/islam-nusant ara/15/03/08/nks07q-muiwaria-tak-boleh-jadi-imam-jamaah-wanita.

Musfirah, Mayadina Rohma. Program Pendampingan Praktek Keberagaman Waria, 2015.

Najmabadi, Afsaneh. Professing Selves: Transsexuality and SameSex Desire in Contemporary Iran, 2014.

"Pakistan: A Legal Victory for Eunuchs - The New York Times." Accessed November 27, 2017. http://www.nytimes. com/2009/12/24/world/asia/24webbriefs-ALEGALVICTOR_ BRF.html. 
"Pesantren Waria Di Yogyakarta Ditutup, LBH Protes." BBC Indonesia. Accessed September 27, 2017. http://www.bbc. com/indonesia/berita_indonesia/2016/02/160225_indonesia_ ponpes_waria_ditutup.

Robertson, Roland, and others. "Glocalization: Time-Space and Homogeneity-Heterogeneity." Global Modernities 2 (1995): $25-45$.

Roxas. "Recognition of a Third Gender: A Reason to Celebrate."

San Francisco Chronicle, July 13, 2017. http://www. sfchronicle.com/opinion/openforum/article/Recognition-of-athird-gender-a-reason-to-11287662.php.

Santoso, Nur. Sekolah Pemikiran Aswaja Dan Teologi Islam PR Eksakta. PMII Komisariat STAI Ibrahimy, Banyuwangi, 2014.

Smith, Wilfred Cantwell. The Meaning and End of Religion. Fortress Press, 1963.

Smith-Hefner, Nancy J. "Javanese Women and the Veil in PostSoeharto Indonesia." The Journal of Asian Studies 66, no. 2 (May 2007): 389-420. https://doi.org/10.1017/S0021911807000575.

"Transgender Pakistanis Win Legal Victories, but Violence Goes On - The New York Times." Accessed December 4, 2017. https:/www.nytimes.com/2017/08/19/world/asia/pakistantransgender-bill.html.

Vasquez, Manuel A, and Marie F Marquardt. Globalizing the Sacred: Religion Across the Americas. Piscataway: Rutgers University Press, 2004. http://site.ebrary.com/id/10075356.

Wahab, Abdul. Islamic Liberation Theology, 2015.

Widyantoro, Hary. "Rethinking the Waria Discourse: The Collaboration between Nahdlatul Ulama Islamic University Activists and Transgender Santri." In Knowledge, Power, and Politics: Where Is Humanity Heading To? Universitas Gadjah Mada: Sekolah Pascasarjana UGM, 2014. http:// webcache.googleusercontent.com/search?q=cache:hk1BJINT ObEJ:igsci.pasca.ugm.ac.id/v2.0/assets/files/igsc-07-054-harywidyantoro.pdf $+\& \mathrm{~cd}=1 \& \mathrm{hl}=\mathrm{id} \& \mathrm{ct}=\mathrm{clnk} \& \mathrm{gl}=\mathrm{nl}$. 
Widyantoro, Hary, and Ph D. Gregory Vanderbilt. "Rethinking Waria Discourse in Indonesian and Global Islam: The Collaboration between Nahdlatul Ulama Islamic University Activists and Waria Santri." Universitas Gadjah Mada, 2015. http://etd.repository.ugm.ac.id/index.php?mod=penelitian_de tail\&sub=PenelitianDetail\&act $=$ view \& typ $=$ ht $m l \& b u k u$ $\mathrm{id}=88126 \&$ obyek_id=4. 